\title{
The impact of depression on the quality of life in elderly people
}

\author{
Wpływ depresji na jakość życia osób w wieku podeszłym - badania \\ pilotażowe
}

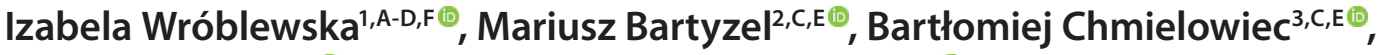 \\ Marta Puścion ${ }^{4, B-C} \oplus$, Jarosław Piotr Chmielewski ${ }^{5, B-C, E-F} \odot$ \\ ${ }^{1}$ Department of Gerontology, Department of Public Health, Faculty of Health Sciences, Medical University, Wrocław, \\ Poland \\ ${ }^{2}$ Mental Health Centre, LUX MED / PROFEMED Group, Warsaw, Poland \\ ${ }^{3}$ Ombudsman for Patients' Rights, Warsaw, Poland \\ ${ }^{4}$ Chair of Civil Law, University of Warsaw, Poland \\ ${ }^{5}$ Higher School of Rehabilitation, Warsaw, Poland \\ A - Research concept and design, B - Collection and/or assembly of data, C - Data analysis and interpretation, \\ $D$ - Writing the article, E - Critical revision of the article, F- Final approval of article
}

Wróblewska I, Bartyzel M, Chmielowiec B, Puścion M, Chmielewski JP. The impact of depression on the quality of life in elderly people. Med Og Nauk Zdr. 2021; 27(2): 199-204. doi: 10.26444/monz/136243

\begin{abstract}
Introduction and objective. Depression is among the most common diseases in the elderly. It affects ca. $15-20 \%$ of people aged over 65 years. The symptomatology of depression is manifested mainly by decreased mood, intellectual skills, concentration and self-esteem, anhedonia, change in appetite, sleep disorders, and the feeling of fatigue and loss of energy. The aim of the article is to assess the impact of depression on the quality of life in elderly people.

Materials and method. The anonymous study involved 140 (100\%) hospitalized patients of a geriatric ward, most of whom (73.57\%) were women. The respondents were 65-88 years old, with the largest group (54.29\%) in the age range 76-85 years. Results. Mild depression was found in $37.86 \%$, and severe depression in $12.14 \%$ of the respondents. Most seniors (42.14\%) assessed their quality of life as good. More than half of the subjects $(55.71 \%)$ declared self-assurance, $45.00 \%$ rarely experienced low spirits, despair, fear, or decreased mood, $40.00 \%$ were not satisfied with their health, $37.14 \%$ were not satisfied with their sleep quality, in $22.14 \%$ pain significantly influenced their everyday life. Patients with depression indicated worse assessments of their quality of life in the somatic, psychological, social, and environmental domains $(p<0.001)$. Statistically significant relationships were observed between quality of life assessment in the somatic domain and the seniors' health status $(p<0.05)$, as well as between quality of life assessment in the environmental domain and the number of diseases $(p=0.034)$.
\end{abstract}

Conclusions. Patients with depression scored their quality of life worse in all domains. In elderly people, quality of life depends on their health status and the number of diagnosed diseases. Seniors living with families indicated better assessments of their quality of life.

\section{Key words}

quality of life, depression, elderly people

Address for correspondence: Jarosław Piotr Chmielewski, Higher School of Rehabilitation, Warsaw, Poland

E-mail: j.chmielewski@ios.gov.pl

Received: 31.03.2021; accepted: 28.04.2021; first published: 14.05.2021

\section{Streszczenie}

Wprowadzenie i cel pracy. Depresja jest jedną z najczęstszych chorób u osób starszych. Dotyka ok. 15-20\% osób w wieku powyżej 65 lat. Objawia się przede wszystkim obniżeniem nastroju, sprawności intelektualnej, koncentracji i samooceny, anhedonią, zmianą apetytu, zaburzeniami snu oraz uczuciem zmęczenia i utratą energii. W niniejszym artykule autorzy ocenią wpływ depresji na jakość życia osób starszych.

Materiał i metody. W anonimowym badaniu wzięło udział 140 (100\%) hospitalizowanych pacjentów oddziału geriatrycznego, z których większość (73,57\%) stanowiły kobiety. Respondenci byli w wieku 65-88 lat, przy czym największa grupa $(54,29 \%)$ mieściła się w przedziale wiekowym 76-85 lat.

Wyniki. Łagodną depresję stwierdzono u 37,86\%, a ciężką u 12,14\% badanych. Większość seniorów (42,14\%) oceniła swoją jakość życia jako dobrą. Ponad połowa badanych $(55,71 \%)$ deklarowała pewność siebie, 45,00\% rzadko doświadczało obniżenia nastroju, rozpaczy, lęku lub obniżonego nastroju, $40,00 \%$ nie było zadowolonych ze swojego stanu zdrowia, $37,14 \%$ nie było zadowolonych z jakości snu, u 22,14\% ból znacząco wpływał na codzienne życie. Pacjenci z depresją gorzej oceniali swoją jakość życia w sferach: somatycznej, psychicznej, społecznej i środowiskowej $(p<0,001)$. Stwierdzono istotne statystycznie zależności między oceną jakości życia w dziedzinie somatycznej a stanem zdrowia seniorów $(p<0,05)$ oraz między oceną jakości życia w dziedzinie środowiskowej a liczbą chorób $(p=0,034)$.

Wnioski. Pacjenci z depresją oceniają swoją jakość życia gorzej we wszystkich aspektach. U osób starszych jakość życia zależy od stanu zdrowia i liczby zdiagnozowanych chorób. Seniorzy mieszkający z rodziną lepiej oceniają swoją jakość życia.

\section{Słowa kluczowe \\ jakość życia, depresja, osoby starsze}




\section{INTRODUCTION}

In recent years, depression has been among the most common diseases reported in industrialized countries [1]. Immediately after dementia, it is the second most frequent psychopathological syndrome in elderly people. Beside falls, immobility, urinary and faecal incontinence, impaired vision and hearing, and dementia, depression belongs to the socalled geriatric giants. Its prevalence in the population aged over 65 years equals 15-20\% [2]. Increased frequency of depression is often found in patients with Parkinson's disease, chronic ischemic heart disease (ca. 18-23\%), neoplasms (ca. $25-50 \%$, depending on the disease stage), history of stroke (26-54\%), and history of a significant coronary event (65\%). In addition, the morbidity increases with age [3].

The overlapping of decreased mood on existing somatic diseases or the reverse situation, namely chronic diseases resulting in the occurrence of depression, make it difficult to diagnose the disease, especially in elderly patients. Moreover, multimorbidity, common among seniors, causes overlapping of symptoms of various diseases and complications associated with treatment. As a result, $25 \%$ of the elderly population report symptoms of depression, with only $20-50 \%$ of these patients having proper diagnosis [4].

Depression is manifested in all spheres of human functioning (physical, mental, social, spiritual, economic); in the elderly, physical functioning is usually the first area where alarming changes can be observed. Seniors begin to complain about numerous ailments, which may be actual symptoms of diseases appearing with age, but may also reflect masked depression. Such symptoms as decreased mood, frustration, feeling of disappointment, despair, or unhappiness, bound with hardships of everyday life or other factors, influence seniors' functioning and change their activity profile, which can lead to a decrease in the quality of life $[5,6]$. When these symptoms increase in severity or frequency, social life functioning also becomes more difficult. If the described condition persists for more than two weeks, depression should be considered, and the diagnosis should result in the implementation of appropriate therapeutic management $[7,8]$.

\section{OBJECTIVE}

The aim of the study was to assess the impact of depression on elderly people's quality of life.

\section{MATERIALS AND METHOD}

The study involved 140 patients of a geriatric ward hospitalized between March 2017 - February 2019 who passed the MiniMental State Examination and provided informed consent to participate in the analysis. The largest group of respondents was aged $76-86(76 ; 54.29 \%)$. They were mainly women $(103 ; 73.57 \%)$, living in the city $(108 ; 77.14 \%)$, had secondary education $(64 ; 45.71 \%)$, were married or widowed (64 each; $45.71 \%$ each), living on retirement pension $(126 ; 90.00 \%)$ and living with family (91; 65.00\%).

Two standardized tools were applied in the study: the full version of the Geriatric Depression Scale (GPS) and the short version of World Health Organization Quality of
Life (WHOQL-BREF). Patients scoring 0-9 points in the Geriatric Depression Scale were classified as people with no depression symptoms, those obtaining 10-19 points as suffering from mild depression, and $\geq 20$ points meant severe depression. The WHOQOL-BREF scale allowed evaluation of seniors' quality of life in the somatic, psychological, social, and environmental domains.

The statistical analysis employed Student's $t$-test and Mann-Whitney $U$-test. The former was used when the distribution of a quantitative variable was normal in all the compared groups, the latter when this assumption was not fulfilled. The analysis of variance (ANOVA) test served to check for differences between more than two groups, and was applied for variables with normal distribution; otherwise, the Kruskal-Wallis test was utilized. In the case of correlation between two quantitative variables, the Spearman correlation coefficient was used. Results at the level of 0.05 were assumed to be significant.

\section{RESULTS}

Numerous chronic diseases were diagnosed among the study participants. More than half $(n=74 ; 52.85 \%)$ declared that they were treated for coronary artery disease; subsequent entities were the following: diabetes $(n=48 ; 34.28 \%)$, endocrine disorders $(n=42 ; 30 \%)$, neoplasms $(n=32 ; 22.85 \%)$, visual impairments $(n=18 ; 12.86 \%)$, history of stroke $(n=6 ; 4.28 \%)$, and Parkinson's disease $(n=4 ; 2.86 \%)$. Half of the respondents $(n=70 ; 50 \%)$ did not have the diagnosis of depression. In the remainder, the Geriatric Depression Scale test confirmed mild depression $(n=53 ; 37.86 \%)$ or severe depression $(n=17 ; 12.14 \%)$.

The WHOQOL-BREF test was characterized by quite high reliability in all its domains. The highest reliability was recorded for the psychological $(\alpha=0.893)$, followed by somatic $(\alpha=0.847)$, environmental ( $\alpha=0.790)$, and social $(\alpha=0.652)$ domains (Tab. 1).

Table 1. Descriptive statistics of WHOQOL-BREF

\begin{tabular}{lcccccc}
\hline Domain & $\mathrm{N}$ & $\mathrm{M}$ & $\mathrm{Me}$ & $\mathrm{SD}$ & Min & Max \\
\hline Somatic & 140 & 13.24 & 13.00 & 3.260 & 5 & 19 \\
\hline Psychological & 140 & 14.33 & 15.00 & 3.394 & 5 & 20 \\
\hline Social & 140 & 14.06 & 15.00 & 3.272 & 7 & 20 \\
\hline Environmental & 140 & 15.12 & 15.50 & 2.606 & 10 & 20 \\
\hline
\end{tabular}

The study subjects were asked to assess their quality of life. The majority $(n=59 ; 42.14 \%)$ indicated a good score, 56 seniors (40\%) described their quality of life as neither good nor bad, $11(7.86 \%)$ as bad, $8(5.71 \%)$ as very good, and 6 $(4.29 \%)$ as very bad.

Another question was whether the respondents were satisfied with their health. Every third $(n=56 ; 40.00 \%)$ stated dissatisfaction, every fourth $(n=36 ; 25.71 \%)$ admitted neither satisfaction nor dissatisfaction, 31 seniors (22.14\%) were satisfied with their health, $9(6.42 \%)$ were very dissatisfied, and $8(5.73 \%)$ turned out very satisfied.

The participants were also asked if physical pain disturbed their everyday functioning. For 41 people $(29.28 \%)$, this was a factor of medium interference, every fifth $(n=34 ; 24.28 \%)$ stated that pain was not an issue for them, 31 seniors $(22.14 \%)$ indicated a significant impact of pain on their everyday lives, 
$18(12.86 \%)$ regarded this factor as slightly significant, and $16(11.44 \%)$ as very significant.

As for sleep quality assessment, the majority $(\mathrm{n}=52 ; 37.14 \%)$ were dissatisfied, 41 (29.28\%) were satisfied, $31(22.14 \%)$ were very dissatisfied, $12(8.57 \%)$ were very satisfied, and 4 (2.87\%) had no opinion. More than half of the subjects $(n=78$; $55.71 \%)$ declared self-assurance, every third $(n=43 ; 30.71 \%)$ was unable to make a clear assessment in this respect, 17 (12.14\%) described themselves as very self-assured, and the remaining two (1.44\%) as not self-assured at all.

The majority of the studied group $(n=63 ; 45.00 \%)$ rarely experienced low spirits, despair, fear, or decreased mood. These feelings never occurred in 29 (20.71\%) seniors, often in $27(19.28 \%)$, very often in $16(11.42 \%)$, and always in five (3.59\%).

The research revealed that people with diagnosed depression scored their quality of life in the somatic, psychological, social, and environmental domains worse than those with no depression symptoms. In the first case, in people with depression $(M=11.00 ; S D=2.60)$, and in subjects with no depression $(M=15.48 ; S D=2.11)$. The result of the $t$ test indicate significance $(\mathrm{t}=-9.451 ; \mathrm{df}=98 ; \mathrm{p}<0.001)$.

In the analysis of the psychological, social, and environmental domains, owing to the failure to meet the requirements of the parametric test, the analyses were based on Mann-Whitey U-test (Tab. 2).

Table 2. Depression and quality of life assessment in the psychological, social, and environmental domains

\begin{tabular}{|c|c|c|c|c|c|c|c|}
\hline \multirow[t]{2}{*}{ Domain } & \multicolumn{3}{|c|}{$\begin{array}{c}\text { Subjects } \\
\text { with depression }\end{array}$} & \multicolumn{3}{|c|}{$\begin{array}{c}\text { Subjects } \\
\text { with no depression }\end{array}$} & \multirow{2}{*}{$\begin{array}{c}\text { Mann-Whitney } \\
\text { test results }\end{array}$} \\
\hline & $\mathrm{Me}$ & Min & Max & $\mathrm{Me}$ & Min & Max & \\
\hline Psychological & 12.00 & 5 & 16 & 17.00 & 13 & 20 & $\begin{array}{l}U=120.00 \\
p<0.001\end{array}$ \\
\hline Social & 12.00 & 7 & 19 & 16.00 & 12 & 20 & $\begin{array}{c}U=377.50 \\
p<0.001\end{array}$ \\
\hline Environmental & 13.00 & 10 & 17 & 17.00 & 12 & 20 & $\begin{array}{l}U=340.50 \\
p<0.001\end{array}$ \\
\hline
\end{tabular}

A relationship was also observed between quality of life assessment in the somatic domain among the studied elderly people and their health status. There were statistically significant differences between groups $(p<0.05)$. The mean score for quality of life was lowest among seniors with three or more diagnosed diseases (multimorbidity). Other groups evaluated their quality of life higher.

To exactly determine which groups were significantly different, Tukey's honestly significant difference (HSD) test was additionally applied. People suffering from at least three diseases $(\mathrm{p}=0.048)$ differed from those with no disease $(p=0.005)$ or with one or two diseases. A greater number of diseases contributed to a lower quality of life assessment in the somatic domain $(\mathrm{p}=0.652)$. The occurrence of one or two diseases, compared with lack of diseases, did not result in a decreased evaluation of quality of life in the somatic domain. In turn, no relationship $(p>0.05)$ was observed between the analysed seniors' marital status or living alone, or with family and the occurrence of depression symptoms. The obtained test result proves that there were no statistically significant differences between these variables.

However, differences were found between elderly people's quality of life assessment in the environmental domain and the number of concomitant diseases. This relationship was not noted in the psychological or social domains $(\mathrm{p}>0.05)$ (Tab. 3).

Table 3. Concomitant diseases and quality of life assessment in the environmental, psychological, and social domains

\begin{tabular}{|c|c|c|c|}
\hline No. of concomitant diseases & M & SD & ANOVA test results \\
\hline \multicolumn{4}{|l|}{ Environmental domain } \\
\hline 0 & 15.90 & 2.537 & \multirow{3}{*}{$\begin{array}{c}F=3.494 \\
d f 1=2 \\
d f 2=97 \\
p=0.034\end{array}$} \\
\hline $1-2$ & 15.32 & 2.471 & \\
\hline$\geq 3$ & 14.28 & 2.614 & \\
\hline \multicolumn{4}{|l|}{ Psychological domain } \\
\hline 0 & 15.10 & 3.044 & \multirow{3}{*}{$\begin{array}{c}F=2.042 \\
d f 1=2 \\
d f 2=97 \\
p=0.135\end{array}$} \\
\hline $1-2$ & 14.56 & 3.359 & \\
\hline$\geq 3$ & 13.47 & 3.598 & \\
\hline \multicolumn{4}{|l|}{ Social domain } \\
\hline 0 & 14.50 & 3.531 & \multirow{3}{*}{$\begin{array}{c}F=2.305 \\
d f 1=2 \\
d f 2=97 \\
p=0.105\end{array}$} \\
\hline $1-2$ & 14.65 & 3.152 & \\
\hline$\geq 3$ & 13.14 & 3.035 & \\
\hline
\end{tabular}

Additionally, in the environmental domain, to exactly determine which groups were significantly different, Tukey's HSD test was applied. The test revealed differences between people with no diagnosed disease and those with three or more diseases $(\mathrm{p}<0.05)$.

It was also investigated whether the studied seniors differed in terms of quality of life assessment in the somatic, psychological, social, or environmental domains, depending on living alone or with family. Those living alone turned out to score their quality of life lower in the enumerated domains.

In the somatic sphere, in people living alone $-\mathrm{M}=12.23$; $\mathrm{SD}=3.71$; however, in the respondents living with their family - $M=13.83$; $\mathrm{SD}=2.88$. The result of the $\mathrm{t}$ test indicated significance $(t=2.382 ; \mathrm{df}=97 ; \mathrm{p}=0.019)$. The results obtained in the remaining three spheres are presented in Table 4.

Table 4. Living alone or with family, and quality of life assessment in the somatic domain

\begin{tabular}{cccccc}
\hline \multirow{2}{*}{ Domain } & \multicolumn{2}{c}{ Living alone } & \multicolumn{2}{c}{ Living with family } & \multirow{2}{*}{ t-test results } \\
\cline { 2 - 4 } & $\mathrm{M}$ & $\mathrm{SD}$ & $\mathrm{M}$ & $\mathrm{SD}$ & \\
\hline Somatic & 12.23 & 3.71 & 13.83 & 2.88 & $\begin{array}{c}t=-2.382 \\
\mathrm{df}=97 \\
\end{array}$ \\
& & & & & $\mathrm{p}=0.019$ \\
\hline
\end{tabular}

It was hypothetically assumed in the study that the severity of depression symptoms depended on the subjects' age. The obtained results confirmed a positive correlation between the variables $(\mathrm{p}<0.05)$, which implies that ageing is accompanied by an increase in the intensity of depression symptoms. However, this correlation was weak (rho $<0.3$ ).

\section{DISCUSSION}

Depression is now among the most common diseases in elderly people $[9,10]$. The study showed that half of the respondents struggle with depressive disorders. A decreased quality of life was also observed in these patients. 
The hypothesis that people suffering from depression scored their quality of life in the somatic domain lower than those not affected by the disease had been indicated earlier by Humańska and Kedziora-Kornatowska [11], who reported the highest deficit among respondents in the physical domain. Their study was performed among geriatric clinic patients and residents of nursing homes. Among 100 analysed seniors, 48 were diagnosed with depression symptoms. Comparable results were obtained by Daly et al. [4] and Naumann and Byrne [12] who examined the relationship between depressive disorders and quality of life, and concluded that quality of life was largely influenced by physical functioning. The worse the physical fitness, the lower the seniors' quality of life proved to be. A study by Rogers also indicates that people with depression much more often complained about increasing symptoms of coronary artery disease, as well as problems with physical fitness; as a result, they scored their quality of life worse. Research also shows that elderly patients with depression symptoms are more likely to report health problems than those without such disorders [13].

The somatic domain acquires special significance in the case of the elderly $[14,15]$. The current study shows that quality of life assessment in this domain depends on seniors' health status. Statistically significant differences occurred between three or more concomitant diseases, which is observed in the majority of elderly patients. Quality of life was evaluated higher by people with fewer diagnosed diseases. These results are not surprising when one takes into account that each disease, especially a chronic one, is associated with a number of ailments, including pain. These, in turn, have a direct impact on the daily lives of elderly people, often significantly impairing their independence $[16,17]$.

The occurrence of diseases is also associated with increased contact with healthcare professionals, and the need for specialized comprehensive diagnostics and treatment which requires an adequate amount of energy. The emergence of multimorbidity in seniors also generates the necessity to take more drugs, may cause polypharmacy, and implies a significant number of adverse events. As a result, a senior can be treated not only for the diagnosed diseases, but also for the emerging adverse events associated with pharmacotherapy. The described phenomenon, manifested by increasing problems in the daily functioning of the elderly person, is called a geriatric cascade and substantially reduces the patient's quality of life, often making them dependent on third party care $[18,19]$.

The deterioration of the senior's functional status decreases their perceived quality of life, which is aggravated by reduced compensatory abilities and more frequent occurrence of concomitant diseases [20]. Analyses performed by Kolotkin [21] imply a lower quality of life indicator in the physical domain among elderly people and show that quality of life depends on disease type and duration. Maciejasz et al. [22] maintain that the level of functioning in everyday personal activities can be the crucial element of quality of life for the elderly.

The social sphere plays a key role in seniors' daily life $[13,23]$. The analyses carried out as part of the presented study reveal that people suffering from depression score their quality of life in this domain lower than those who are healthy. Personal relationships with other people, including the support that the patient receives from their relatives, have a significant impact on the senior's well-being [24,
25]. Lack of help may decrease the well-being, therefore raising the likelihood of depression, which is confirmed by numerous studies conducted among elderly people [26, 27]. Limitation of social contacts may also lead to deterioration of general performance, negatively affecting all spheres of functioning [11].

Family is an important factor to be considered when analysing impacts on an elderly person's quality of life [24, 28]. It was proved that seniors living with families scored their quality of life higher than those living alone. Family support turns out to be especially significant when the patient is burdened with numerous diseases and needs care. Elderly people are often unable to function independently and to meet their basic needs, in which case support from relatives is essential. Some authors maintain that a chronic disease is a source of negative emotions in seniors and lowers their quality of life. Family support and lack of loneliness are extremely important for a better perception of life quality, but still remain individual issues. Sometimes, elderly people living in a shared household with younger representatives of their families, assess their general well-being less favourably than those living alone. One should also bear nd that living alone does not necessarily imply that the senior feels lonely [22].

Living alone, however, has been reported to constitute an additional factor contributing to the occurrence of depression. Numerous studies have shown that people living alone are more likely to develop depressive conditions. This is associated with a reduced number of social contacts, alienation, or family conflicts [3]. Seniors who have the possibility to live with families are less exposed to depression [29], as confirmed by the presented study and the obtained statistically significant differences between the groups of people living alone and with families. Loneliness and independent living as a significant risk for depression in seniors is also supported by studies by other authors [30,31].

\section{RESULTS}

The current study also reveals that seniors living with families indicate higher scores in quality of life assessment in the psychological domain. The reason may be a high self-esteem and a sense of being useful. The case of seniors' quality of life evaluation in the social domain proved to be similar. A number of studies show that elderly people living alone, especially women and those with low socio-economic status, are more likely to be affected by three or more chronic diseases. To a large extent, this translates into reduced quality of life and experiencing psychological stress. The condition makes it extremely difficult to regain physical fitness [32]. Living with family and good interpersonal relationships are important for seniors' proper functioning in their home environment. This definitely implies a high assessment of their perceived quality of life, which has been proved by many researchers in their analyses $[11,27,33]$. They indicate that the main source of support is the patient's life partner and then friends, i.e. the support network, reported as the main factor counteracting social isolation and exclusion of the elderly from their surrounding environment [27].

Interestingly, the study did not confirm a relationship between the respondents' marital status and the severity of their depression symptoms. A comparable number of married 
and single seniors, including those who experienced loss of a loved one, took part in the study. Subject literature shows that over $16 \%$ of widows, within one year after the death of their spouse, experience clinically significant depression due to a prolonged period of sadness and loneliness $[2,14]$. The presented research confirms that the development of depressive disorders is affected by the death of the spouse. An important factor here is the time elapsing from the partner's death; the shorter the time, the more visible and better diagnosed the decreased mood symptoms are [11].

The presented study shows that seniors with depression score their quality of life lower than those without the disease also in the environmental domain. Similar result were obtained by Pacian et al. [34]. The environmental domain is related, among others, to satisfaction with housing conditions, health care, or public transport. Seniors also evaluate the opportunity to pursue their interests, which is particularly disturbed by depression. This opportunity score also reflects the respondents' feelings about their safety in everyday life, and about the immediate environment being conducive to their health. Correspondingly, the environmental domain analysis allows to determine whether the financial resources available to the elderly are sufficient to meet their needs [29].

This study reveals that quality of life assessment in the environmental domain also depended on the senior's health status. Housing conditions, which to a large extent can translate into the occurrence of diseases, are also important. The financial situation is of great significance, as the lack of measures may affect the treatment and its level, and thus contribute to a deterioration of health status. Elderly people who do not have sufficient financial resources neglect a proper, healthy diet, as well as their interests, which impacts on their well-being. They also lose their sense of security, easily translating into quality of life. This is confirmed by research concerning the influence of income and housing on the perception of quality of life among the elderly [22]. It has been proved that people with diseases and low material status rate their quality of life less favourably [27]. In addition, elderly people with low socio-economic status are more often affected by three or more diseases, which implies lower quality of life [22].

Among seniors, the main factor influencing quality of life perception is the place of residence, with highest rating ascribed to own house. Living in the same place for years allows regular personal contacts with friends and acquaintances. Observation shows that elderly people living in their own homes or with families, present greater independence, activity, and initiative, feel more confident as they can count on the help of their loved ones. In a familiar environment, they feel more autonomous, free, and selfreliant [32].

The presented study shows that patients with symptoms of depression score their quality of life in the psychological domain lower than those not affected by the disease. This remains in line with research by other authors. Fernandez et al. [35] revealed that among the analysed seniors, psychological factors negatively affected the quality of life. Attention deficit, anhedonia, and lower drive are often observed in people with depression disorders. Elderly patients sometime do not become not self-assured, experience problems with acceptance of their appearance, reflect on the sense of their lives, and experience negative feelings, such as low spirits, despair, or fear [34].
The current study also proves that the severity of depression symptoms depends on the subjects' age. Other studies confirm that ageing is bound with more frequent occurrence of depression, as well as with lower quality of life assessment in the psychological and social domains $[23,27]$.

The ageing of the human body takes place in several stages and on many levels. It is a process-shaped over many years of life, most often considered from several aspects: physical (involving the body and sense organs), social (manifested in one's activity in social life), and mental (referring to feelings and the mind). Ageing causes loss of internal balance of the body, leads to abnormal functioning of cells, tissues, organs, and systems. As a result, increased susceptibility to many diseases occurs. Multimorbidity, in turn, often deteriorates everyday life functioning, and can thus significantly impair the senior's quality of life [3].

\section{CONCLUSIONS}

1. Depression disorders involve a considerable proportion of elderly patients.

2. The severity of depression symptoms increases with age.

3. Seniors living with families indicate better assessments of their quality of life.

4. Patients with depression score their quality of life worse in all domains.

5. In elderly people, quality of life depends on their health status and the number of diagnosed diseases.

\section{Conflict of interest}

The authors declare that they have no conflicts of interest.

\section{REFERENCES}

1. Dols A, Kupka RW, van Lammeren A, et al. The prevalence of latelife mania: a review. Bipolar Disord. 2014; 16(2): 113-118. https://doi. org/10.1111/bdi.12104

2. Sajatovic M, Strejilevich SA, Gildengers AG, et al. A report on older-age bipolar disorder from the International Society for Bipolar Disorders Task Force. Bipolar Disord. 2015; 17(7): 689-704. https://doi.org/10.1111/ bdi.12331

3. Aziz R, Steffens D. Overlay of Late-Life Depression and Cognitive Impairment. Focus. 2017; 15(1): 35-41. https://doi.org/10.1176/appi. focus. 20160036

4.Livingston G, Huntley J, Sommerlad A, et al. Dementia prevention, intervention, and care: 2020 report of the Lancet Commission. Lancet. 2020 https://doi.org/10.1016/s0140-6736(20)30367-6

5. Orgeta V, Mukadam N, Sommerlad A, et al. The Lancet Commission on Dementia Prevention, Intervention, and Care: A call for action. Ir J Psychol Med. 2018; 36(2): 85-88. https://doi.org/10.1017/ipm.2018.4

6. Kivimäki M, Singh-Manoux A. Prevention of dementia by targeting risk factors. Lancet. 2018; 391(10130): 1574-1575. https://doi.org/10.1016/ s0140-6736(18)30578-6

7. Tipton PW, Graff-Radford NR. Prevention of late-life dementia what works and what does not. Pol Arch Intern Med. 2018; 128: 310-316. https://doi.org/10.20452/pamw.4263

8. Singh-Manoux A, Dugravot A, Fournier A, et al. Trajectories of Depressive Symptoms Before Diagnosis of Dementia: A 28-Year Follow-up Study. JAMA Psychiatry. 2017; 74(7): 712-718. https://doi. org/10.1001/jamapsychiatry.2017.0660

9. Imaoka M, Nakao H, Nakamura M, et al. Associations between depressive symptoms and geriatric syndromes in community-dwelling older adults in Japan: A cross-sectional study. Prev Med Rep. 2021; (10)22: 101353. https://doi.org/10.1016/j.pmedr.2021.101353

10. Warren JD, Bamiou DE. Prevention of dementia by targeting risk factors. Lancet. 2018; 391(10130): 1575. https://doi.org/10.1016/S01406736(18)30579-8 
11. Humańska MA, Kędzierska-Kornatowska K. Correlation among intensification of depressive states and the feeling of life quality in the elderly. Psychogeriatria Polska. 2009; 6(1): 15-22. http://www.fozp.org. pl/wpcontent/uploads/pgp/2009_pgp_6_1_humanska.pdf

12. Pilania M, Yadav V, Bairwa M, et al. Prevalence of depression among the elderly (60 years and above) population in India, 1997-2016: a systematic review and meta-analysis. BMC Public Health. 2019; 19(1): 832. https:// doi.org/10.1186/s12889-019-7136-z

13. Hanyu H. Prevention of Dementia-with Special Reference to Lifestyle and Vascular Risk Factors. Brain Nerve. 2018; 70(3): 191-198. https:// doi.org/10.11477/mf.1416200981

14. Park JS, Lee J, Jung ES, et al. Brain somatic mutations observed in Alzheimer's disease associated with aging and dysregulation of tau phosphorylation. Nature Communications. 2019; 10(1): 3090. https:// doi.org/10.1038/s41467-019-11000-7

15. Sandberg M, Ahlström G, Axmon A. et al. Somatic healthcare utilisation patterns among older people with intellectual disability: an 11-year register study. BMC Health Serv Res. 2016; 16: 642 https://doi. org/10.1186/s12913-016-1880-x

16. Kessler RC, Bromet EJ. The Epidemiology of Depression Across Cultures. Annu Rev Public Health. 2013; 34(1): 119-138. https://doi.org/10.1146/ annurev-publhealth-031912-114409

17. Dixon J, Karagiannidou M, Knapp M. The Effectiveness of Advance Care Planning in Improving End-of-Life Outcomes for People With Dementia and Their Carers: A Systematic Review and Critical Discussion. J Pain Symptom Manage. 2018; 55(1): 132-150.e1. https://doi.org/10.1016/j. jpainsymman.2017.04.009

18. Tunvirachaisakul C, Gould RL, Coulson MC, et al. Predictors of treatment outcome in depression in later life: A systematic review and meta-analysis. J Affect Disord. 2018; 227: 164-182. https://doi. org/10.1016/j.jad.2017.10.008

19. Andre KKA, McKibbin CL, Wykes TL, et al. Depression Treatment Among Rural Older Adults: Preferences and Factors Influencing Future Service Use. Clin Gerontol. 2013; 36(3): 241-259. https://doi.org/10.10 80/07317115.2013.767872

20. Burzynska M, Bryla M, Bryla P, et al. Factors determining the use of social support services among elderly people living in a city environment in Poland. Health Soc Care Community. 2015; 24(6): 758-768. https:// doi.org/10.1111/hsc.12259

21. Kolotkin RL, Binks M, Crosby RD, et al. Obesity and sexual Quality of Life. Obesity. 2006; 14(3): 472-479. https://doi.org/10.1038/oby.2006.62

22. Maciejasz M, Łatkowski W, Timoszuk S. et al. Selected aspects of quality of life of people aged 60+ in Poland in qualitative research, Studia Ekonomiczne. 2015; 223: 257-267. http://yadda.icm.edu.pl/ yadda/element/bwmeta1.element.desklight-e0a96379-1383-4295-9ce3$4 \mathrm{~d} 40 \mathrm{c} 0 \mathrm{c} 70334$
23. Huber D, Milne S, Hyde KF. Constraints and facilitators for senior tourism. Tourism Management Perspectives, 2018; 27: 55-67. https:// doi.org/10.1016/j.tmp.2018.04.003

24. Beard JR, de Carvalho IA, Sumi Y, et al. Healthy ageing: moving forward. Bull World Health Organ. 2017; 95(11): 730-730A. https:// doi.org/10.2471/BLT.17.203745

25. Chatterji S, Byles J, Cutler D, et al. Health, functioning, and disability in older adults-present status and future implications. Lancet. 2015; 385(9967): 563-75. https://doi.org/10.1016/S0140-6736(14)61462-8

26. Su D, Wu XN, Zhang YX, et al. Depression and social support between China' rural and urban empty-nest elderly. Arch Gerontol Geriatr. 2012; 55(3): 564-569. https://doi.org/10.1016/j.archger.2012.06.006

27. Ornstein KA, Kelley AS, Bollens-Lund E, et al. A National Profile Of End-Of-Life Caregiving In The United States. Health Aff. 2017; 36(7): 1184-1192. https://doi.org/10.1377/hlthaff.2017.0134

28. Moyle W, Murfield J, Venturto L, et al.Dementia and its influence on quality of life and what it means to be valued: Family members' perceptions. Dementia. 2013; 13(3): 412-425. https://doi. org/10.1177/1471301212474147

29. Na L, Streim JE. Psychosocial Well-Being Associated With Activity of Daily Living Stages Among Community-Dwelling Older Adults. Gerontol Geriatr Med. 2017; 3: 233372141770001. https://doi. org/10.1177/2333721417700011

30. Starczewska ME, Prociak L, Rybicka A. Assessment of the functionalcapacity and the risk of depression among seniors. Pielęg Pol. 2019; 3(73): 258-264. https://doi.org/10.20883/pielpol.2019.34

31. Knyszyńska A, Radecka A, Bryczkowska I. et al. The relationship between functional efficiency and the level of depression among residents of Social Welfare Houses. Gerontol Pol. 2019; 27: 144-149. https://www.akademiamedycyny.pl/wp-content/uploads/2019/12/ Knyszy\%C5\%84ska.pdf

32. Ostrzyżek A, Marcinkowski J. Dimensions of the quality of life in old age. Probl Hig Epidemiol. 2009; 90(4): 465-469. http://www.phie.pl/ pdf/phe-2009/phe-2009-4-465.pdf

33. Vogelzangs N, Kritchevsky S, Beekman A. Depressive symptoms and change in abdominal obesity in older persons, Arch Gen Psychiatry. 2008; 65(12): 1386-1393. https://doi.org/10.1001/archpsyc.65.12.1386

34. Pacian A, Kulik T, Chruściel P, et al. Quality of life and risk of depression among elderly people. Hygeia Public Health. 2014; 49(4): 820- 824. http:// www.h-ph.pl/pdf/hyg-2014/hyg-2014-4-820.pdf

35. Fernandez-Munoz JJ, Ciqaran-Mendez M, Navarro-Pardo E, et al. Is the association between health-related quality of life and fatigue mediated by depression in patients with multiple sclerosis? A Spanish crosssectional study. BMJ Open. 2018; 8(1): e016297. https://doi.org/10.1136/ bmjopen-2017-016297 